\title{
Islamic Economic Thoughts of Prominent Muslim Scholars in the Abbasid Era
}

Nur Amani Aisyah Samsuddin, Nadhirah Nordin, Rahimah Embong, Suraya Ismail, Rossidi Usop \& Siti Khatijah Ismail

To Link this Article: http://dx.doi.org/10.6007/IJARBSS/v10-i12/8212

DOI:10.6007/IJARBSS/v10-i12/8212

Received: 12 October 2020, Revised: 10 November 2020, Accepted: 01 December 2020

Published Online: 12 December 2020

In-Text Citation: (Samsuddin et al., 2020)

To Cite this Article:Samsuddin, N. A. A., Nordin, N., Embong, R., Ismail, S., Usop, R., \& Ismail, S. K. (2020). Islamic Economic Thoughts of Prominent Muslim Scholars in the Abbasid Era. International Journal of Academic Research in Business and Social Sciences, 10(12), 26-35.

Copyright: () 2020 The Author(s)

Published by Human Resource Management Academic Research Society (www.hrmars.com)

This article is published under the Creative Commons Attribution (CC BY 4.0) license. Anyone may reproduce, distribute, translate and create derivative works of this article (for both commercial and non-commercial purposes), subject to full attribution to the original publication and authors. The full terms of this license may be seen at: http://creativecommons.org/licences/by/4.0/legalcode

Vol. 10, No. 12, 2020, Pg. 26 - 35

Full Terms \& Conditions of access and use can be found at http://hrmars.com/index.php/pages/detail/publication-ethics 


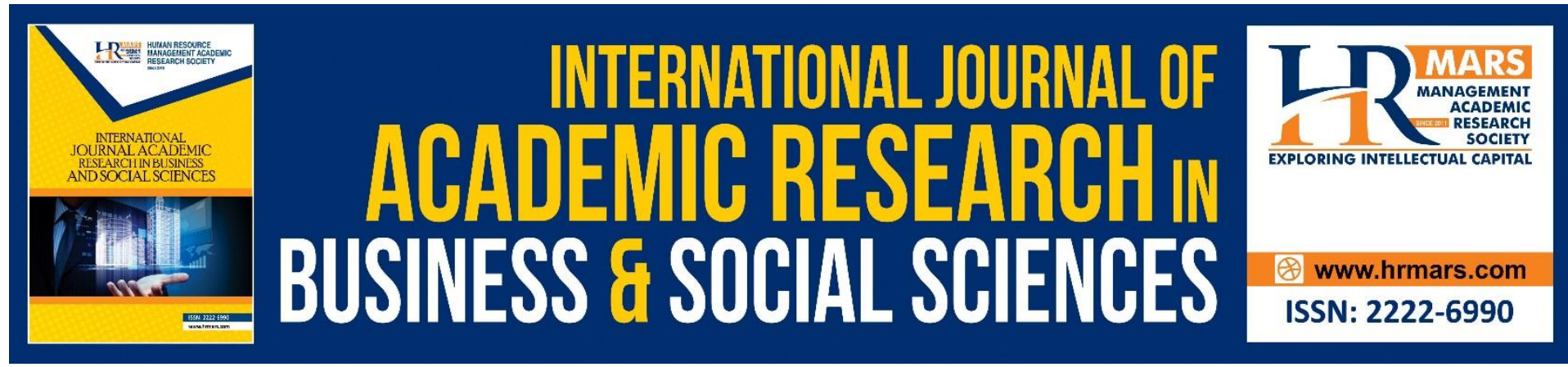

\title{
Islamic Economic Thoughts of Prominent Muslim Scholars in the Abbasid Era
}

\author{
Nur Amani Aisyah Samsuddin ${ }^{1}$, Nadhirah Nordin², Rahimah \\ Embong $^{3}$, Suraya Ismail ${ }^{4}$, Rossidi Usop ${ }^{5}$ \& Siti Khatijah Ismail ${ }^{6}$ \\ ${ }^{1}$ Faculty of Islamic Contemporary Studies, Universiti Sultan Zainal Abidin, 21300 Kuala \\ Terengganu, Terengganu, Malaysia, ${ }^{2}$ Faculty of Islamic Contemporary Studies, Universiti \\ Sultan Zainal Abidin, 21300 Kuala Terengganu, Terengganu, Malaysia, ${ }^{3}$ Faculty of Islamic \\ Contemporary Studies, Universiti Sultan Zainal Abidin, 21300 Kuala Terengganu, \\ Terengganu, Malaysia, ${ }^{4}$ Faculty of Economics and Management Sciences, Universiti Sultan \\ Zainal Abidin, 21300 Kuala Terengganu, Terengganu, Malaysia, ${ }^{5}$ Genius Insan College, \\ Universiti Sains Islam Malaysia, ${ }^{6}$ Faculty of Islamic Contemporary Studies, Universiti Sultan \\ Zainal Abidin, 21300 Kuala Terengganu, Terengganu, Malaysia.
}

Email: noramani96@gmail.com.my

\begin{abstract}
This article aims to review previous studies related to the economic thought of Muslim scholars during the Abbasid era. Literature review has been done throughout this qualitative study using primary and secondary sources. Thought is an opinion and ijtihad (reasoning) in decision making according to thought process is accurate. Debates on Islamic economics scientifically and systematically existed before the advent of conventional economics. Therefore, these Islamic economic thoughts need to be re-highlighted in order to develop a holistic economic system. It has found that the development of Islamic economic thought in the Abbasid era emphasized the principle of justice in every economic activity, especially in business and trade. In addition, the national treasury system also plays an important role in developing the economic system in a country.
\end{abstract}

Keywords: Islamic Economic Thoughts, Abbasid Era.

\section{Introduction}

Islamic economic thought is a pattern of thinking related to economic aspect based on the Qur'an and the Sunnah, developed by Muslim scholars through their writings. Islamic economic thought is a process of ijtihad (reasoning or intellectual endeavour) among Muslim thinkers or scholars based on legal sources and other sources of support aimed at finding solutions to basic problems in various fields including the field of muamalat and economics faced by the Muslim community. The aspiration is to explain a view and pattern of Islamic thought to elucidate economic problems based on the Qur'an, al-Sunnah, ijma, qiyas and maqasid al-shariah, and methodologies related to ijtihad (Nordin, Mohammad, Ahmad, Haron, \& Daud, 2017). Ijtihad in the context of Islamic economic thought refers to the use of 
Islamic legal resources as well as the importance of welfare and the rejection of harm (AlDurini, 1988).

Muslim thinkers helped a lot in developing a country during the Islamic rule, especially in the Islamic economy, to coordinate the implementation of a fair and equal income system for individuals, communities and countries. Islamic thought began at the period of Rasulullah p.b.u.h. Then and there, Islamic economics was simple in which the principles were based on the revelation of the Holy Qur'an and his ijtihad (Mudhiiah, 2016). In addition, there are also studies that discuss the Islamic economic thinking at the time of the Umayyads. Among the principles discussed are the right to individual freedom, the right to property, economic inequality, social security and others (Indasari, 2017).

Subsequently Islamic economic thought reached to the time of the Abbasids in $749 \mathrm{M}$ or more precisely in $750 \mathrm{M}$ led by Abu Abbas As-Safah (Meriyati, 2018). Islamic economic thinkers have laid the foundations for the construction of the Islamic economic system, which includes the resources, principles, methods and techniques of implementation (Salamon, 1988). Although there are many differences, they make the Quran and Hadith as the absolute source of reference. This study aims to penetrate Islamic economic thinking in the time of the Abbasids for the achievements among prominent figures in that era in helping to improve and control the economic system by creating methods and means of implementation based on Islam. The Islamic economic thinkers to be studied namely Abu Yusuf, Muhammad bin al Hasan, Abu Ubaid, Al Mawardi, Al Ghazali, Ibn Taimiyah and Ibn Khaldun. These figures were chosen because of their expertise in giving assessments and recommendations to the government in developing systems and ways of implementing an Islamic economy that promoting well-being of people.

\section{Methodology}

The methodology of this study was qualitative approach and exploratory in nature. The content analysis method was used to analysed selected documents regarding the contribution of Islamic economic thinkers that include book, journals, articles, theses and academic papers.

\section{Discussion}

The Islamic economy of the Abbasid period flourished during the reign of Caliph Harun ArRashidin. This occurs since the Islamic thinkers of that time have issued a thought that is relevant and consistent according to Islamic law and based on the Qur'an and Hadith. Among the Islamic economic thinkers to be highlighted are

\section{Abu Yusuf's Economic Thought (113 H-182 H)}

Abu Yusuf or Ya'qub bin Ibrahim bin Habib bin Khunais bin Sa'ad Alanshari Al-Jalbi Al-Kufi AlBaghdadi. He was born in $113 \mathrm{H}$ in Kufah (Al-Baghdady, 1989). Abu Yusuf's thinking emphasizes on taxation and national responsibility. His thoughts had been expressed in his book al-Kharaj which was written during the time of Caliph Harun al-Rashid and has been used as a reference by modern Islamic economists. According to Karim (2004), Abu Yusuf's thinking showed that all economic activities and facilities that benefit the community become a responsibility of the government, but if the benefits are only given to certain people only, then fines and payments will be imposed on the unjust government (Yusuf, 1979). Therefore, in order to achieve the well-being of society, the country has the right to impose taxes such 
as $\mathrm{fa}^{\prime} \mathrm{i}^{1}$, ushur ${ }^{2}$, jizyah $^{3}$ and others as the income for the country (Saprida, 2017; Oky, 2019; Baba et al., 2010). In addition, Abu Yusuf also replaced the misahah tax system (fixed tax) to the taxation muqasamah (proportional tax) as well as against the Qabalah ${ }^{4}$ system (Center for Research and Development of the Islamic Economy, 2008) because it involved oppression for the poor (Abu Yusuf, 1399; Boedi, 2010).

\section{Al-Syaibani's Economic Thought (132 H-189 H)}

Al-Syaibani or Abu Abdillah Muhammad bin Al-Hasan bin Farqad Al- Syaibani. Born in $132 \mathrm{H}$ in the city of Wasith, the capital of Iraq at the end of the Umayyad rule (Boedi, 2010). AlSyaibani had started studying with Abu Hanifah when he was 14 years old for four years before Abu Hanifah died. Afterwards, he studied with Abu Yusuf, one of the leading students and considered a successor to Abu Hanifah (Chamid, 2010). Islamic economists refer to the book of al-Kasb to reveal the economic thought of Al-Syaibani. The writing of the book is a response of the author to the development and emergence of asceticism in the second century AH (Euis, 2010). Overall, this book is about micro-economic studies that revolve around al-kasb (income) theory and its resources as well as behaviour in production and consumption activities (Al-Syaibani, t.th). This book is also listed as the first book in the Islamic world that discusses micro-economic problems. Therefore, it is not excessive when Al-Janidal declares Al-Syaibani as one of the pioneers of Islamic economics (Euis, 2010).

Al-Syaibani has defined al-Kasb (income) as an effort in obtaining property through halal means. In economics, such activities belong to production activities (Al-Syaibani, t.th). However, in the Islamic economy, not all activities that produce goods or services are considered production activities, because it is strictly related to the law of halal haram in obtaining a good or service. This means that a halal-only economy will be considered a production activity. Al-Syaibani states that economic activities are divided into four, namely sinaah (industrial), ijarah (rental rental), ziraah (agriculture) and tijarah (trade) (Al-Syaibani, t.th; Wally, 2018). While contemporary economists categorize the economy into three, namely agriculture, industry, and services. If observed in depth, these service labours are inclusive of trade labours. However, among these four economic activities, Al-Syaibani prioritizes agricultural activities because agriculture can meet various basic human needs and prioritized in the implementation of various obligations (Chamid, 2010).

\section{Abu Ubaid Economic Thought (150 H-224 H)}

Abu Ubaid or al-Qasim bin Sallam bin Miskin bin Zaid al-Harawi al-Azadi al-Baghdadi was born in $150 \mathrm{H}$ in the city of Harrah, Khurasan, north-western Afghanistan (Rizal, 2018). Abu Ubaid produced the book Al-Amwal which is a work on public finance. It is extremely rich of history of legal science. Justice is the main principle emphasized by Abu Ubaid in this book. The implementation of this principle of justice will indirectly create prosperity in the economy and can harmonize social equality between individuals, society and the country. However, if there is a dispute between the interests of individuals and society, then the priority belongs to the interests of the public and society (Abu Ubaid, t.th: Wally, 2018; Ningsih, 2013). Kitab Al-

\footnotetext{
${ }^{1}$ Property acquired by the Muslims from the enemy in the war without going through the war because it was abandoned by its owner.

${ }^{2}$ Import tax imposed on the trader, paid only once a year and only applies to goods worth over 200 dirhams.

${ }^{3}$ Taxes are imposed on non-Muslims who reside in Islamic countries and will fall if they convert to Islam.

${ }^{4}$ Qabalah is a system of tax payment through guarantors based on the membership owned.
} 
Amwal discusses the Islamic public financial system, especially in the field of administration and governance comprehensively (Junaidi \& Abdulmuhaimin, 2017).

Abu Ubaid also stressed the national treasury so that the rulers do not use the power given for personal gain as it should be used for public interest solely (Abu Ubaid, n.d). In addition, Muslims are also prohibited from imposing taxes on non-Muslims excessive to the amount specified in the agreement. Abu Ubaid also explained that tax payments should not be increased, but can be reduced when people are incapable to pay them. It also states that if a non-Muslim applies for a tax-free application, then it will be allowed when he gets a guarantee from a Muslim and the value of merchandise is equal to the amount of tax imposed on him, then he will be exempt from import tax (duty free) (Wally, 2018). Abu Ubaid also stressed to the collectors of kharaj, jizyah, ushur or zakat to not torture the community while collecting taxes and hoped that the community could overcome the financial problem (Abu Ubaid, t.th). Abu Ubaid sought to avoid discrimination and favouritism, namely oppression in taxation and attempts to avoid paying taxes (Karim, 2014).

According to Karim (2017) and Euis (2010), the public financial system and the value of money are interrelated. Abu Ubaid explained in his book, the function of money is divided into two, namely as a standard of exchange value and a medium for exchange.

Karim (2017) also explains that Abu Ubaid supports the conventional theory of coins, although it does not explain the reason why gold and silver are not eligible. However, it is allowed if gold and silver are the prices of goods and services. This is because, Abu Ubaid supports the economic theory of coins only to general use while gold and silver have a fixed value compared to other groups. If it is used as an exchange tool, then its value will change. In addition, Abu Ubaid also indirectly stated that the function of money is also as a store of value.

\section{Al-Mawardi's Economic Thought (364 H-450 H)}

Abu Al-Hasan Ali bin Muhammad bin Habib Al-Mawardi Al-Basri Al-Syafi'i was born in the city of Basrah, Iraq in $364 \mathrm{H}$ (Boedi, 2010). Al-Mawardi discusses economic issues in his two books entitled Al-Ahkam Al-Sulthoniyyah and Adab Al-Din Wa'l Dunya.

His first book related to governance and administration which is about the obligations of the government, the entry and production of the country, land (country and society), the right of the state in donating land, the obligation of the state in maintaining the market and others. Al-Mawardi also explained that market surveillance is the duty of the muhtasib ${ }^{5}$, to maintain security and price control as well as to prevent irregularities during activities in trade and business. In addition, the system of government and administration of the Islamic state, such as the rights and obligations of the government to its people, various state institutions, entry and production of the country, as well as hisbah institutions are important to ensure smooth economic activities (Nashihah, 2018; Usop et al., 2019; Isaak, 2014).

While in his second book, Adab Al-Din Wa'l Dunya, he discusses the behaviour of consumers of Islamic economics individually. The book conveys the teachings of Sufism related to the behaviours, actions and morals of individuals in carrying out any economic activity (AlMawardi, n.d.).

Next, Al-Mawardi is of the view that in meeting the basic needs of every member of society in carrying out economic activities, the government and the country should provide facilities and repair existing infrastructure so that economic activities such as business and trade can

\footnotetext{
${ }^{5}$ Security assigned to control and guard the market area.
} 
be expanded and security systems to maintain the welfare of the public can be upgraded. According to him, if living in the city becomes a problem because of the lack of functioning facilities or the existence of damage to the place, then the government and the state should be responsible to improve it and if there are no funds, the state should seek for it. Al-Mawardi also stressed that the state must compile and bear the expenses required by the public because not all communities can afford the facilities provided (Al-Mawardi, n.d.). Therefore, service to the public is a social obligation (fardh kifayah).

Al-Mawardi also mentions that the duties of the state in the framework of meeting the basic needs of every society are to provide a conducive economic system, provide spending through baitul mal, provide justice and also implement Islamic law, collect revenue and income from various sources and implement tax system new to maintain the well-being of society.

In addition to elaborating on the theory of public expenditure, Al-Mawardi apparently understood the impact of the economic shift caused when the income was fixed (Al-Mawardi, n.d.). He states that every decrease in public wealth is an increase in national wealth and every decrease in national wealth is an increase in public or community wealth. Thus AlMawardi argues that public spending, such as taxation is an effective tool to increase economic resources (Yaakub, 2009).

\section{Al-Ghazali's Economic Thought (451 H-505 H)}

The full name of Al-Ghazali is Hujjatul Islam Abu Hamid Muhammad bin Muhammad Al-Tusi Al-Ghazali. He was born in Tus in $451 \mathrm{H}$, a small town in Khurasan, Iran (Badawi, 1957). AlGhazali's insights and knowledge related to the economy are very broad, especially about market evolution, the role of money and determinants in income (Arief, 2018).

Al-Ghazali focuses on individual behaviour described in detail based on the Quran, al-Hadith and ljma. He is of the view that every human being should take care of the necessities of life and always worship Allah SWT. Al-Ghazali warns that the leader should ensure the well-being of his people (Al-Ghazali, t.t). According to Siddiqi (1992), Al-Ghazali gives an opinion on the exchange of goods (barter) that is appropriate to do according to the equality of value or amount required based on mutual agreement. He also explained about the incompatibility of some goods or values when exchanging to maintain the importance and function of money at that time.

Ghazali (1991) and Al-Misri (1981) think that the function of currency according to Al-Ghazali's thinking is as a basis for value, medium of exchange and value for savings. Therefore, currency cannot be used as an exchange tool with the currency itself, unless there is a purchase using that currency with an item and then the item is resold with an agreed profit (Yusof, Borhan, \& Romli, 2016).

\section{Ibn Taimiyah's Economic Thought (661 H-728 H)}

His full name is Taqi al-Din Ahmad bin Abd. Al-Halim bin Abd. Salam bin Taimiyah. He was born in $661 \mathrm{H}$ in Harran which is part of the Roman sultanate which is now known as the Syrian state.

Ibnu Taimiyyah has categorized the theory of justice for economic activity into three things, namely wages, profits and prices (Ibnu Taimiyyah, t.th; Islahi, 1988). According to him, the concept of fair price means that when a person sells his goods openly then the goods are bought at the same time and place. Ibnu Taimiyyah also equated the concept with modern economics which is the market mechanism (Center for Islamic Economic Studies and Development (P3EI), 2008). Ibnu Taimiyyah argues that an increase in the demand for goods 
which is not followed by an increase in the supply or production of goods will lead to an increase in the price of goods (Mujahidin, 2013; Siddiqi, 1968; Kahf, 1978; Mubarak, 1972). In order to maintain justice and meet basic needs during the reduction of goods, then the pricing must be determined by the government so that there is no monopoly on prices and goods (Yaakub, 2009; Ibnu Taimiyyah, n.d.). Islahi (2005) explained Ibnu Taimiyyah has conceptualized to the determination of the wage rate. The stipulation of payment is intended to avoid the exploitation and injustice of the payment of wages or salaries from the government to the workers. This statement also shows that labour supply and demand theory has influenced wage payment rates.

Ilt is a fact that bnu Taimiyyah has made great contributions to the Islamic economy through his work namely the book al-Hisbah fi al-Islam and al-Siyasah al-Sharia'ah Fi Islah al-Ra'y wa Ra'iyah (Yaakub, 2009; Hasan, 2011). Both works are related to market mechanisms and prices that should be implemented and managed by the government, property rights, money, usury prevention during transactions carried out by producers and traders, the role of the country in well managing the economy, management in maintaining welfare and infrastructure facilities to traders and public traders as well as others. He also states that the price of goods is based on the total supply and demand from customers (Ulhaq \& Achiria, 2018).

\section{Ibn Khaldun's Economic Thought (732 H-845 H)}

Ibn Khaldun or his real name was Abdurrahman Abu Zaid Waliuddin Ibn Khaldun born in Tunisia at the beginning of Ramadan $732 \mathrm{H}$ (Maarif, 1996). Ibn Khaldun has his own opinion regarding the dynamic factors of moral, social, economic and political, but interrelated in the effort to develop society (Anto, 2003). His book, Muqaddimah is his writing and views on Islamic economics. Ibn Khaldun had an in-depth knowledge of the principles of Islamic economics. Even his thinking is still relevant and used as a guide and policy by modern Islamic economists (Chapra, 2001). In his analysis, Ibn Khaldun has divided the price of goods into two parts namely, the first basic necessities and the second complementary goods. It states that as a market grows and its population increases (the number of traders increases), then doubling of basic necessities will become a priority and will lead to an increase in orders (Ibn Khaldun, 2000).

According to Borhan (2000), Ibn Khaldun's contribution is highlighted through his work Muqaddimah including the theory of production, division of labour and exchange (El-Alfi, 1968; Mannan, 1989). This theory described by Ibn Khaldun asserts that economic life is one form of implementing a balance of supply and demand, the relationship between total production and consumption rate as well as the rate of payment of wages based on total production demand of goods (Arif, 2007). Skill factors among workers or labour will affect the total production of each item, this is because categorization according to labour skills will facilitate the movement of work (Ibn Khaldun, 1967). Indirectly, it will increase production rates and create surplus goods that can be used to exchange with others or export to other countries to increase wealth.

\section{Discussion Summary}

Based on research between those periods, the actions and theories built by Islamic economic thinkers are to transfer all human beings to the same prosperity and social justice.

There are similarities related to theories put forward by Islamic economic thinkers throughout their reign. There are similarities between the prominent figures such as Abu Ubaid and Al- 
Mawardi who emphasized the treasury system in controlling the country's economic system where the government should take care of the welfare of the community by ensuring infrastructure facilities and public safety are guaranteed. The infrastructure facilities to facilitate transactions in business and trade activities run smoothly. In addition, with the presence of securities who control the market area will be able to protect the safety of traders and sellers from fraud and oppression of workers.

In addition, Abu Yusuf, Muhammad Al-Syaibani, Al-Ghazali, Ibn Taimiyyah and Ibn Khaldun stressed that every economic activity carried out should be based on justice and equity in conducting business activities. Abu Yusuf explained that every tax imposed on traders and sellers should be commensurate with the rate of quantity and value of goods brought. While Muhammad Al-Syaibani stated that every income earned must be in a halal way only without discrimination against the rights of others. Al-Ghazali, Ibn Taimiyyah and Ibn Khaldun, on the other hand, emphasized the fairness of the price of goods and the payment of salaries and wages to workers. They stressed that justice for the matter so that there is no exploitation of the price of goods and salaries to the workforce. According to him, the price and production of each item is based on the total supply and demand in the market only. Furthermore, it will avoid the occurrence of riba, gharar and intentional price increases (Nordin et al., 2019).

\section{Conclusion}

It can be concluded that the theory of Islamic economic thought put forward by these figures is to safeguard the welfare of all parties to achieve happiness in this world and the hereafter. Islamic economic thinkers strongly emphasize justice so that there is no riba $^{6}$, gharar ${ }^{7}$, deliberate price increase, oppression of workers, exploitation of goods and information related to the great duties and responsibilities as a government to ensure stability, comfort, convenience to traders as it is one of the sources of income for national economy.

\section{Corresponding Author}

Nur Amani Aisyah Samsuddin, is graduate research assistant (GRA) in Faculty of Islamic Contemporary Studies, Universiti Sultan Zainal Abidin (UniSZA), Gong Badak Campus, 21300 Kuala Nerus, Terengganu, Malaysia.

Email: noramani96@gmail.com.my

\section{Acknowlegement}

It is acknowledged that this article is an output of Fundamental Research Grant Scheme (FRGS), FRGS/1/2019/SS08/UNISZA/02/1 granted by the Ministry of Education. We also express our deepest gratitude to Center for Research Excellence \& Incubation Management (CREIM) and Faculty of Islamic Contemporary Studies, Universiti Sultan Zainal Abidin, Terengganu.

\section{References}

Al-Baghdady, Al-khatib. (1989). Tarikh al-baghdad. Beirut: Dar Al-Fikri.

Al-Durini, F. (1988). Nazariyat al-Ta'asuffi isti 'mal al-Hagg. Beirut: Muassasah al-Risalah.

Al-Ghazali. (n.d). Ihya ulum ad-din. Beirut: Dar An Nadwah. (Jld 2).

Al-Misri, R. Y. (1981). Al Islam wa'l nuqud. Jeddah: International Centre For Research In Islamic Economics.

\footnotetext{
${ }^{6}$ Riba is an additional charge imposed on a person for some reason.

${ }^{7}$ Gharar is a transaction or contract that is banned because of doubts between the seller and the buyer.
} 
Anto, H. (2003). Pengantar ekonomika mikro Islami. Yogyakarta: Ekonisia.

Arief, N. (2018). Pemikiran ekonomi Islam Abu Ubaid (154-224 h): fungsi uang dan relevansinya saat ini. MPRA Paper 90588. Germany: University Library of Munich.

Arif, H. (2007). Ekonomi Islam: pengantar analisis kesejarahan dan metodologi. Malang: BPFE UNIBRAW.

Baba, Z. S., Jusoh, H., Muda, H., \& Ab Rahman, S. M. A. S. (2010). Tanggapan Usahawan Terhadap Zakat Perniagaan Berbanding Cukai Pendapatan Perniagaan di Terengganu. Jurnal Islam dan Masyarakat Kontemporari, 3, 97-113.

Borhan, J. T. (2000). Sumbangan Ibn Khaldun dalam pemikiran ekonomi Islam dan relevensinya dengan permasalahan ekonomi semasa. Jurnal Akidah \& Pemikiran Islam. 1(1). 155-176.

Chamid, N. (2010). Jejak langkah sejarah pemikiran ekonomi Islam. Pustaka Pelajar.

Chapra, M. U. (2001). The future of economics: an Islamic perspective. Jakarta: Shariah Economics and Banking Institute.

El-Alfi, E. S. (1968). Production, distribution and exchange Ibn Khaldun's. Disertasi tesis PHD. University Minnesota.

Ghazali, A. (1991). Islamic thinkers on economics, administration and transactions. (Vol 1). Quill Publishers.

Ibn-Khaldun. (2000). Muqaddimah. Jakarta: Pustaka Firdaus.

Ibn-Khaldun. (1967). The muqaddimah. Terj. Franz Rosenthal. (Vol 3). New York.

Indasari, D. (2017). Perkembangan pemikiran ekonomi Islam pada masa Bani Umayyah. Jurnal Ilmu Pengetahuan Teknologi \& Seni. 9(2). 55-60.

Isaak, P. (2014). Creative writing activities and TPR plus: An implementation of foreign language development project to students with dyslexia. Multilingual Academic Journal of Education and Social Sciences, 2(1), 36-57.

Islahi, A. A. (1988). Economic concept of Ibn Taimiyah. Leicester: Islamic Foundation.

Islahi, A. A. (2005). Contributions of muslim scholars to the history of economic thought and analysis up to 15th century. Jeddah: Scientific Publisher Center.

Junaidi, S., \& Abdulmuhaimin, F. (2017). "Analisis perbandingan pemikiran Abu Ubaid AlQasim dan Adam Smith mengenai perdagangan". Millah: Jurnal Studi Agama. 17 (1).

Kahf, M. (1978). The Islamic Economy: Analytical of the Functioning of the Islamic Economic System. Plainfield, Ind.: Muslim Students Association of US and Canada.

Karim, A. A. (2017). Sejarah pemikiran ekonomi Islam. (Cet 8). Depok: PT Raja Grafindo Persada.

Karim, A. A. (2014). Sejarah pemikiran ekonomi Islam. Depok: Raja Grafindo Persada.

Karim, A. A. (2004). Sejarah pemikiran ekonomi Islam. (Cet 3). Jakarta: PT. Raja Grafindo Persada

Maarif, A. S. (1996). Ibn Khaldun dalam pandangan penulis barat dan timur. Gema Insani.

Meriyati. (2018). "Perkembangan ekonomi Islam pada masa daulah Abbasiyah." Islamic Banking. Vol. 4(1). 45-56.

Mubarak, M. (1972). Nizam al-Islam al-lqtisad, mabadi wa qawa'id 'amma. Beirut: Dar al-fikr. Mudhiiah, K. (2016). Analisis sejarah pemikiran ekonomi Islam masa klasik. IQTISHADIA. 8(2). Mujahidin, A. (2013). Ekonomi Islam: sejarah, konsep, instrumen, negara dan pasar. Jakarta: Raja Grafindo Persada.

Nashihah, F. (2018). Countries, economy and markets: Analysis of hisbah institution and its contribution to Al-Mawardi perspective. Retrieved 12 january 2020, from https://mpra.ub.uni-muenchen.de/id/eprint/87029 
Nordin, N., Embong, R., Daud, N., Ismail, S. K., Salleh, S. F., \& Ahmad, A. A. (2019). The Islamic Ethical Principles in Commodity Derivatives Contracts. Journal of Legal, Ethical and Regulatory Issues. 22 (1). 226-235.

Nordin, N., Mohammad, M., Ahmad, A. A., Haron, M. S., \& Daud, N. (2017). Commodity Futures: A Maqasid Al-Shariah Based Analysis, International Journal of Academic Research in Business and Social Sciences. 7(4). 602-614.

Oky, R. (2019). Teori pajak menurut Abu Yusuf sebuah alternatif solusi perpajakan di Indonesia. IQTISHODUNA: Jurnal Ekonomi Islam. 8(1). 1-32.

Rizal, F. (2018). Relevansi pemikiran ekonomi Islam Abu Ubaid dengan perekonomian modern. ACTIVA: Jurnal Ekonomi Syariah. 1(1). 110-129.

Salamon, S. (1988). Perniagaan menurut pandangan Islam. Selangor: Bahagian Hal Ehwal Islam Jabatan Perdana Menteri.

Saprida, M. H. I. (2017). Sejarah pemikiran ekonomi Islam. Palembang: Perpustakaan Nasional Katalog Dalam Terbitan (KDT).

Siddiqi, M. N. (1968). Islam ka nazariyah e-milkiyat (Urdu). Lahore.

Siddiqi, M. N. (1992). Islamic economic thought: recent works on history of economic thought in Islam, a survey, reading in Islamic thought. Malaysia: Longman.

Hasan, S. K. (2011). Ekonomi Islam: Pengenalan. Kuala Lumpur: Dewan Bahasa dan Pustaka.

Ulhaq, M. Z., \& Achiria, S. (2018). Pemikiran Ibn Taimiyah tentang regulasi harga pasar dalam Islam. Iqtishodia: Jurnal Ekonomi Syariah. 3(1). 58-71.

Usop, R., Zainol, F. A., Nordin, N., Wahab, N. A., Masud, W. A. (2019). Amalan Etika Perniagaan Islam dalam kalangan Usahawan Islam: Kajian Kes di Syarikat Noor Arfa Holdings Sdn. Bhd. Journal of Management and Operation Research (jomor). 1(2). http://doi.org/10.5281/zenodo.3252719.

Wally, S. (2018). Sejarah pemikiran ekonomi Islam Al Syaibani dan Abu Ubaid. Tahkim. 14(1). 124-144.

Yaakub, E. (2009). Beberapa aspek pemikiran ekonomi dan kewangan Islam. Selangor: Pusat penerbitan Universiti (UPENA) UiTM.

Yusof, M. F. M., Borhan, J. T., \& Romli, N. (2016). Pemikiran ekonomi al-Ghazali dalam teori kewangan (the al-Ghazali economic thought in the financial theory). UmranInternational Journal of Islamic and Civilizational Studies. 3(3).

Yusuf, A. (1979). Kitab al-kharaj. Beirut: Dar al-Ma'arif. 